\title{
Haemodynamic and myocardial metabolic effects of captopril in chronic heart failure
}

\author{
KANU CHATTERJEE, JEAN-LUCIEN ROULEAU, * WILLIAM W PARMLEY \\ From the Cardiovascular Division of the Department of Medicine and the Cardiovascular Research Institute, \\ University of California, San Francisco, Califormia, USA
}

SUMMAR I In 15 patients with chronic left ventricular failure caused by ischaemic heart disease, cardiac output and right heart pressures were measured before and after the oral angiotensinconverting enzyme inhibitor, captopril, which was administered in increasing doses. In 12 of 15 patients, coronary blood flow, and in 11 patients myocardial oxygen extraction and consumption and lactate extraction were also determined before and after captopril therapy. Cardiac index and stroke volume index increased by an average of $25 \%$ and $27 \%$, respectively. Pulmonary capillary wedge pressure also decreased in all patients (average 27\%), suggesting improved left ventricular function. The rate-pressure product, coronary blood flow, and myocardial oxygen consumption decreased significantly; in one of 11 patients there was myocardial lactate production, despite decreased myocardial oxygen demand and consumption. These findings suggest that in patients with chronic heart failure, improved left ventricular function with captopril is generally associated with decreased metabolic cost and that deterioration of metabolic function occurs infrequently.

That angiotensin-converting enzyme inhibitor, captopril, is a potent antihypertensive agent is well established. ${ }^{2}$. Recently, improvement of left ventricular function and amelioration of symptoms of heart. failure with captopril have also been documented in normotensive patients. ${ }^{3-8}$ Thus, captopril appears to have a potential role for the longterm management of patients with chronic heart failure.

Although beneficial haemodynamic effects of captopril are observed in most patients, little information is available regarding its effects on coronary circulation. In many patients, ischaemic heart disease is the underlying aetiology of chronic heart failure. The evaluation of changes in coronary haemodynamics and myocardial metabolism is particularly relevant in this subset of patients. The purpose of this study, therefore, is to assess not only changes in left ventricular function, but also changes in coronary haemodynamics and myocardial metabolism with captopril in patients with chronic heart failure resulting from ischaemic heart disease.

\section{Subjects and methods}

Fifteen patients with congestive heart failure of more than two months' duration formed the patient popula-

$\star$ Dr Rouleau is a recipient of the McLaughlin Fellowship from McGill University School of Medicine, Canada.

Accepted for publication 24 Augúst 1981 tion. All patients were male and their ages ranged from 46 to 70 years. All patients had at least one documented myocardial infarction; all 15 patients had electrocardiographic evidence of anterior myocardial infarction. Four of 15 patients had selective coronary arteriography and all four had severe triple vessel coronary artery disease.

At the time of the study, all patients had clinical evidence of biventricular failure with pulmonary artrial hypertension. Chest $x$-ray fims showed significant cardiomegaly in all patients. Twodimensional echocardiograms and/or radioangiograms showed the presence of a dilated, poorly contracting left ventricle in all 15 patients. Ten patients were in New York Heart Association Class III, and five were in Class IV heart failure at the time of the study.

All vasodilator drugs were discontinued at least four days before the study. Digoxin and diuretics were continued and given every evening after completion of the study. After obtaining written consent, a triple lumen balloon flotation catheter was placed in the pulmonary artery percutaneously via the right subclavian vein. Right atrial pressure, pulmonary artery pressure, pulmonary capillary wedge pressure, and cardiac output by thermodilution (triplicate) were determined with this balloon flotation catheter. ${ }^{9}$ For measurement of coronary sinus flow and for obtaining coronary sinus venous blood samples, a No. 8 thermodilution coronary sinus flow catheter (Wilton 
Webster Co., California) was placed in the coronary sinus percutaneously via the left subclavian vein. In order to minimise coronary sinus reflux, the catheter was positioned under fluoroscopy near the great cardiac vein. ${ }^{10}$ Arterial pressure was recorded directly by cannulating the radial artery.

Coronary sinus flow was measured by the constant infusion thermodilution technique. ${ }^{11}$ Coronary sinus flow was calculated by the formula:

$\left(\frac{\mathrm{Tb}-\mathrm{Ti}}{\mathrm{Tb}-\mathrm{Tm}}\right)-\times 1.08 \times 46 \mathrm{ml} / \mathrm{min}$, where $\mathrm{Tb}=$ temperature of blood, $\mathrm{Ti}=$ temperature of mixture of blood and the injectate, $1.08=a$ constant accounting for specific heart and density of both blood and injectate, $46 \mathrm{ml} / \mathrm{min}$ is the injection rate of the injectate. Arterial and coronary sinus venous blood samples were drawn simultaneously for the determination of oxygen saturation, $\mathrm{O}_{2}$ content, and lactate concentration. The lactate concentration was measured using the enzymatic fluorometric method of Loomis, ${ }^{12}$ and the oxygen $\left(\mathrm{O}_{2}\right)$ saturations were measured using a Corning 175 automated blood and $\mathrm{pH}$ analyser.

The haemodynamic and metabolic vanables were calculated as follows:

Cardiac index (CI), $1 / \mathrm{min}$ per $\mathrm{m}^{2}=$ cardiac output/body surface area; stroke volume index (SVI), $\mathrm{ml} / \mathrm{m}^{2}=\mathrm{CI} / \mathrm{HR}$, where $\mathrm{HR}=$ heart rate; stroke work index (SWI), $\mathrm{g} \mathrm{m} / \mathrm{m}^{2}=$ SVI $\times($ MSP-PCWP $) \times$ 0.0136 , where MSP $=$ mean systolic pressure and PCWP = mean pulmonary capillary wedge pressure.

Systemic vascular resistance (SVR), dynes $\mathrm{s} \mathrm{cm}^{-5}$ $=($ MAP-RAP $) / C O \times 80$, where $M A P=$ mean arterial pressure, $\mathrm{RAP}=$ mean right atrial pressure.

Myocardial oxygen extraction (Art $-\mathrm{CSO}_{2}$ ), volume $\%=$ arterial $\mathrm{O}_{2}$ - coronary sinus $\mathrm{O}_{2}$ content .

Myocardial $\mathrm{O}_{2}$ consumption $\left(\mathrm{MVO}_{2}\right), \mathrm{ml} / \mathrm{min}=$ coronary sinus flow $\times\left(\mathrm{Art}-\mathrm{CSO}_{2}\right) \times 10^{-2}$.

Myocardial lactate extraction (\% lactate) $=$ $\underline{\text { Arterial-coronary sinus }}$ Arterial

\section{CAPTOPRIL ADMINISTRATION}

After the insertion of the catheters, patients were allowed to rest for one hour, and two sets of control measurements were obtained 15 minutes apart, before oral administration of captopril. Our previous experience $^{5}$ suggested that significant hypotension may occur in some patients if the initial dose of captopril is $25 \mathrm{mg}$. Therefore, in this study, a smaller $(2.5 \mathrm{mg})$ dose was given initially, and then the dose was increased to $6 \cdot 25,12 \cdot 5,25,50,100$, and $150 \mathrm{mg}$ every two hours until there was a $10 \mathrm{mmHg}$ fall in mean arterial pressure. In individual patients, the next larger dose was not given when a fall in arterial pressure was noted with the previous smaller dose. All 15 patients tolerated 2.5 and $6.25 \mathrm{mg}$ doses; in one patient, the dose could not be increased after $6.25 \mathrm{mg}, \frac{\mathrm{C}}{\mathrm{C}}$ in four after $12.5 \mathrm{mg}$, and in nine after $25 \mathrm{mg}$. In only $\overrightarrow{\vec{F}}$ one patient could the dose be increased to $50,100, \stackrel{\vec{S}}{?}$ and $150 \mathrm{mg}$. Measurements of systemic and coronary? haemodynamics and metabolic variables were repeated two hours after each dose. Throughout the $\frac{\bar{\sigma}}{\bar{\phi}}$ study period care was taken to ensure that the coronary $\stackrel{\odot}{\varrho}$ sinus catheter remained in the same position by $\%$ repeated fluoroscopy and injection of contrast medium. $\vec{\circ}$

STATISTICAL ANALYSIS

Paired analysis between control and the peak effects $\stackrel{\omega}{\stackrel{2}{2}}$ of captopril for each variable was performed using the paired " $t$ " test. When the effects of different doses $\stackrel{t}{-}$ were compared, a two-way analysis of variance was $\omega$ done using the Student-Newman-Keuls test.

\section{Results}

Because only one patient received a dose larger than $25 \mathrm{mg}$, the haemodynamic and metabolic effects of $\frac{\bar{\partial}}{\partial}$ 50,100 , or $150 \mathrm{mg}$ dose of captopril were excluded $\overrightarrow{\vec{\theta}}$ when the dose response effects were analysed. The $\stackrel{\odot}{\infty}$ average haemodynamic and metabolic response to 2.5 , $6.25,12.5$, and $25 \mathrm{mg}$ oral doses of captopril are summarised in Table 1. After a $2.5 \mathrm{mg}$ dose no appreciable changes in haemodynamics were observed $\bar{O}$ in any of the 15 patients. After a $6.25 \mathrm{mg}$ dose, mean $\stackrel{2}{0}$ arterial pressure fell, and after $25 \mathrm{mg}$, there was a $18 \% \stackrel{\unrhd}{\unrhd}$ decrease in mean arterial pressure. There was a $\overrightarrow{\overrightarrow{0}}$ gradual decrease in systemic vascular resistance, and 3 it fell by $30 \%$ after the $25 \mathrm{mg}$ dose. Cardiac index increased by an average of $20 \%$ after the $25 \mathrm{mg}$ dose. Stroke volume index also increased in all but one patient. There was also a significant fall in pulmonary capillary wedge, right atrial, and pulmonary arterial pressures. Changes in stroke work index were variable 3. and were not statistically significant.

Heart rate tended to decrease with increasing doses of captopril, though the average changes did not reach statistical significance. The product of peak systolic pressure and heart rate (rate-pressure product), how- $\frac{D}{0}$ ever, decreased significantly, and after the $25 \mathrm{mg}$ dose there was an average decrease of $15 \%$. Coronary sinus $N$ flow and myocardial oxygen consumption were $N$ determined in 12 of the 15 patients, and myocardial N oxygen consumption and lactate extraction were ${ }_{\sigma}$ determined in 11 patients. Coronary sinus flow and myocardial oxygen consumption also tended to decrease with increasing doses of captopril. As not $\stackrel{\oplus}{\rightarrow}$ every patient received all the doses of captopril, however, and as in individual patients the peak effects were observed after different doses, the average $\underset{\mathbb{D}}{ }$ changes in coronary sinus flow and myocardial oxygen $\frac{O}{\mathbb{D}}$ consumption after each dose did not reach statistical $\frac{\varrho}{\sigma}$ significance. There was a tendency to decreased 
Table 1 Systemic haemodynamic response (mean $\pm S D$ ) to increasing doses of captopril in patients with chronic heart failure

\begin{tabular}{|c|c|c|c|c|c|}
\hline $\begin{array}{l}\text { Captopril dose (mg) } \\
\text { Heart rate (beats/min) } \\
\text { Mean arterial pressure (mmHg) } \\
\text { Pulmonary capillary wedge pressure } \\
\quad(\mathbf{m m H g})\end{array}$ & $\begin{array}{r}0 \\
80 \pm 15 \\
82 \pm 10 \\
24 \cdot 3 \pm 5 \cdot 3\end{array}$ & $\begin{array}{r}2 \cdot 5 \\
81 \pm 13 \\
78 \pm 10 \\
23 \cdot 4 \pm 7 \cdot 7\end{array}$ & $\begin{aligned} & 6 \cdot 25 \\
80 & \pm 14 \\
75 & \pm 9 \star \star \star \\
22 \cdot 3 & \pm 8 \cdot 0\end{aligned}$ & $\begin{aligned} & 12 \cdot 5 \\
79 & \pm 11 \\
71 & \pm 11^{\star \star} \\
21 \cdot 7 & \pm 8 \cdot 3\end{aligned}$ & $\begin{array}{c}25 \\
78 \pm 12 \\
67 \pm 12^{\star \star} \\
19 \cdot 7 \pm 7 \cdot 6^{\star \star \star}\end{array}$ \\
\hline $\begin{array}{l}\text { Right atrial pressure }(\mathrm{mmHg}) \\
\text { Cardiac index }\left(1 / \mathrm{min} \text { per } \mathrm{m}^{2}\right) \\
\text { Stroke volume index }\left(\mathrm{ml} / \mathrm{m}^{2}\right) \\
\text { Stroke work index }\left(\mathrm{g} \mathrm{m} / \mathrm{m}^{2}\right) \\
\text { Systemic vascular resistance } \\
\left.\text { (dynes } \mathrm{cm}^{-5}\right)\end{array}$ & $\begin{array}{c}12 \pm 6 \\
2 \cdot 0 \pm 0 \cdot 5 \\
26 \pm 8 \\
30 \cdot 5 \pm 14 \\
1552 \pm 397\end{array}$ & $\begin{array}{c}12 \pm 6 \\
2 \cdot 0 \pm 0 \cdot 5 \\
26 \pm 8 \\
29 \cdot 0 \pm 13 \cdot 3 \\
1506 \pm 718\end{array}$ & $\begin{array}{c}11 \pm 5 \\
2 \cdot 1 \pm 0 \cdot 5 \\
27 \pm 7 \\
29 \cdot 6 \pm 12 \cdot 1 \\
1380 \pm 311\end{array}$ & $\begin{array}{c}11 \pm 5 \\
2 \cdot 2 \pm 0 \cdot 5 \\
29 \pm 8 \\
30 \cdot 6 \pm 15 \cdot 7 \\
1189 \pm 274^{\star}\end{array}$ & $\begin{array}{c}11 \pm 5 \\
2 \cdot 4 \pm 0 \cdot 5^{\star \star \star} \\
31 \pm 9 \star \star \star \\
30 \cdot 0 \pm 13 \cdot 9 \\
1078 \pm 295^{\star \star \star}\end{array}$ \\
\hline $\begin{array}{l}\text { Peak systolic pressure times } \\
\text { heart rate }\left(\mathrm{mmHg} / \mathrm{min} \times 10^{-3}\right)\end{array}$ & $10 \cdot 2 \pm 2 \cdot 3$ & $9 \cdot 8 \pm 2 \cdot 0$ & $9.4 \pm 2.2$ & $8 \cdot 8 \pm 2 \cdot 2^{\star \star \star}$ & $8 \cdot 2 \pm 2 \cdot 3^{\star \star}$ \\
\hline $\begin{array}{l}\text { Coronary sinus flow (ml/min) } \\
\text { Lactate extraction (vol \%) } \\
\text { Myocardial oxygen consumption } \\
\quad\left(\mathrm{ml} / \mathrm{min} \times 10^{-2}\right)\end{array}$ & $\begin{array}{c}63 \cdot 2 \pm 21 \cdot 6 \\
35 \pm 16 \\
12 \cdot 7 \pm 2 \cdot 0\end{array}$ & $\begin{array}{c}60 \cdot 5 \pm 24 \cdot 4 \\
36 \pm 17 \\
12 \cdot 7 \pm 1 \cdot 9\end{array}$ & $\begin{array}{c}57 \cdot 8 \pm 23 \cdot 3 \\
40 \pm 18 \\
12 \cdot 8 \pm 1 \cdot 8\end{array}$ & $\begin{array}{c}59.2 \pm 27.8 \\
35 \pm 15 \\
12.4 \pm 1.9\end{array}$ & $\begin{array}{c}60 \cdot 2 \pm 28 \cdot 7 \\
34 \pm 29 \\
12 \cdot 1 \pm 2 \cdot 1\end{array}$ \\
\hline
\end{tabular}

myocardial oxygen extraction after 12.5 and $25 \mathrm{mg}$ doses, and the average myocardial lactate extraction remained unchanged.

The peak haemodynamic effects in individual patients occurred after different doses of captopril. The peak haemodynamic effects of captopril were defined when the mean arterial pressure fell by at least $10 \mathrm{mmHg}$. The average changes in the peak systemic and coronary haemodynamics and in metabolic variables are summarised in Table 2 , and illustrated in Fig 1, 2, and 3. The peak haemodynamic effects were characterised by a significant decrease in mean and diastolic blood pressures, heart rate, and systemic vascular resistance. Cardiac index and stroke volume index increased significantly by an average of $25 \%$ and $27 \%$, respectively. There was also a distinct fall in pulmonary capillary wedge pressure (Fig 1). Improvement in left ventricular function was indicated by the concomitant increase in cardiac and stroke volume indices and decrease in pulmonary capillary wedge pressure (Fig. 2).

The product of peak systolic pressure and heart rate (rate-pressure product) decreased significantly, and there was also a concomitant decrease in coronary sinus flow and myocardial oxygen consumption (Fig. 3). Myocardial oxygen extraction decreased slightly, and this decrease in Art- $\mathrm{CSO}_{2}$ was the result of an increase in coronary sinus $\mathrm{O}_{2}$ content. The average transmyocardial lactate extraction remained unchanged. The relation between the changes in rate-pressure product and coronary sinus flow, and myocardial oxygen consumption in individual patients, is illustrated in Fig. 4. In all patients ratepressure product decreased and coronary sinus flow decreased in 11 of the 12 patients. Myocardial $\mathrm{O}_{2}$ consumption also decreased in 10 of the 11 patients. Thus, in almost all patients improved left ventricular function was associated with decreased metabolic cost. There was myocardial lactate production in only one of 11 patients, and in the other 10 patients lactate extraction remained unchanged.

\section{Discussion}

That angiotensin-converting enzyme inhibitor, captopril, produces beneficial haemodynamic effects in patients with chronic heart failure has been documented in many previous studies. ${ }^{3-8}$ In the present study, a similar beneficial haemodynamic

Table 2 Peak haemodynamic and metabolic effects (mean $\pm S D$ ) of captopril in chronic heart failure

\begin{tabular}{|c|c|c|c|c|}
\hline & No. of parients & Control & Captopril & Probability \\
\hline $\begin{array}{l}\text { Heart rate (beats/min) } \\
\text { Mean arterial pressure (mmHg) } \\
\text { Diastolic arterial pressure (mmHg) } \\
\text { Pulmonary capillary wedge pressure } \\
(\mathbf{m m H g})\end{array}$ & $\begin{array}{l}15 \\
15 \\
15 \\
15\end{array}$ & $\begin{array}{r}80 \pm 15 \\
82 \pm 10 \\
61 \pm 10 \\
24 \cdot 2 \pm 5 \cdot 3\end{array}$ & $\begin{array}{c}75 \pm 12 \\
64 \pm 10 \\
47 \pm 8 \\
17 \cdot 6 \pm 5 \cdot 1\end{array}$ & $\begin{array}{l}0.01 \\
0.001 \\
0.001 \\
0.001\end{array}$ \\
\hline $\begin{array}{l}\text { Cardiac index }\left(\mathrm{l} / \mathrm{min} \text { per } \mathrm{m}^{2}\right) \\
\text { Stroke volume index }\left(\mathrm{ml} / \mathrm{m}^{2}\right) \\
\text { Peak systolic pressure times } \\
\text { heart rate }\left(\mathrm{mmHg} / \mathrm{min} \times 10^{-3}\right)\end{array}$ & $\begin{array}{l}15 \\
15 \\
15\end{array}$ & $\begin{array}{r}2 \cdot 0 \pm 0 \cdot 5 \\
25 \cdot 7 \pm 8 \cdot 0 \\
10 \cdot 2 \pm 2 \cdot 3\end{array}$ & $\begin{array}{r}2 \cdot 5 \pm 5 \cdot 1 \\
32 \cdot 7 \pm 7 \cdot 0 \\
7 \cdot 6 \pm 1 \cdot 9\end{array}$ & $\begin{array}{l}0.001 \\
0.001 \\
0.001\end{array}$ \\
\hline $\begin{array}{l}\text { Coronary sinus flow (ml/min) } \\
\text { Myocardial } \mathrm{O}_{2} \text { extraction (vol \%) } \\
\text { Myocardial } \mathrm{O}_{2} \text { consumption }(\mathrm{ml} / \mathrm{min}) \\
\text { Myocardial lactate extraction }(\%)\end{array}$ & $\begin{array}{l}12 \\
11 \\
11 \\
11\end{array}$ & $\begin{array}{c}63 \cdot 2 \pm 21 \cdot 6 \\
12 \cdot 7 \pm 2 \\
8 \cdot 2 \pm 2 \cdot 8 \\
35 \pm 16\end{array}$ & $\begin{array}{c}55 \cdot 8 \pm 24 \cdot 7 \\
12 \pm 2 \\
6 \cdot 6 \pm 3 \cdot 1 \\
38 \pm 20\end{array}$ & $\begin{array}{l}0.025 \\
0.025 \\
0.025 \\
\text { NS }\end{array}$ \\
\hline
\end{tabular}

NS= not significant. 

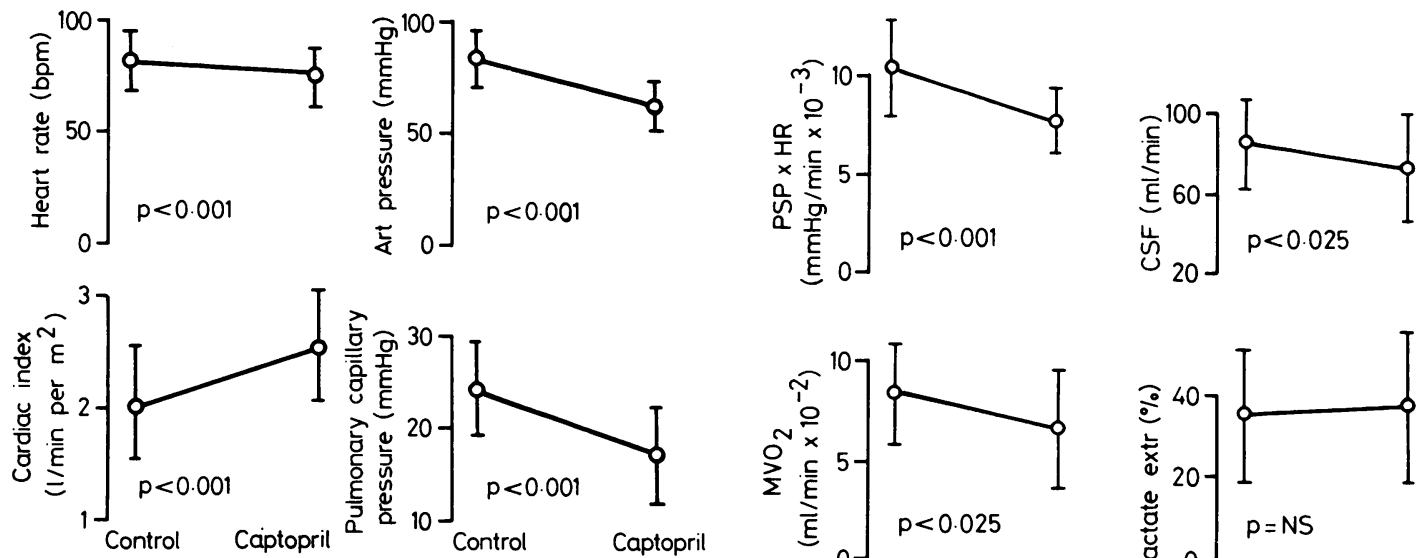

Fig. 1 Changes in heart rate, mean arterial pressure, cardiac index, and pulmonary capillary wedge pressure at peak effect of captopril. Heart rate, arterial pressure, and pulmonary capillary wedge pressure decreased and cardiac index increased.
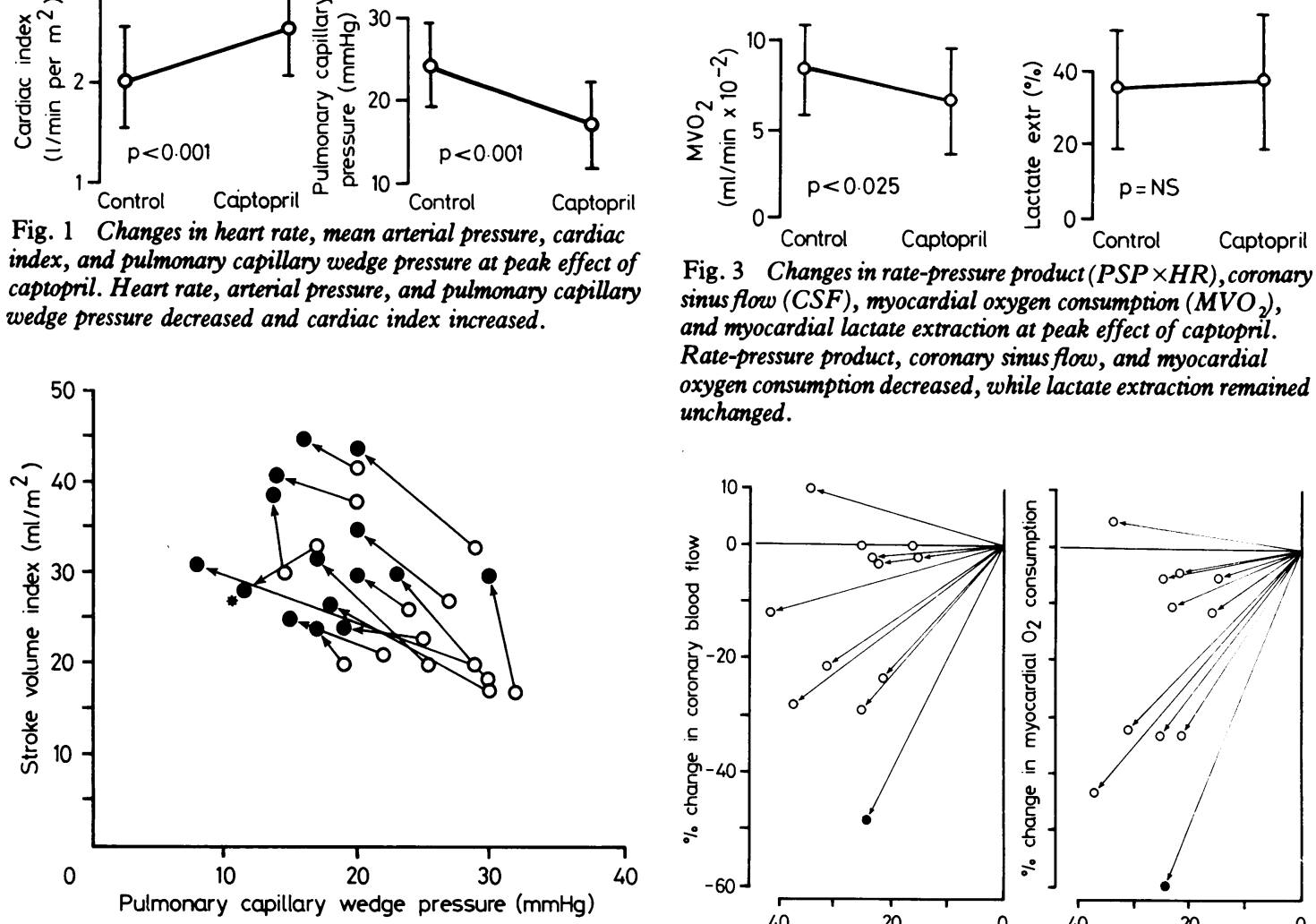

Fig. 3 Changes in rate-pressure product $(P S P \times H R)$, coronary sinus flow (CSF), myocardial oxygen consumption $\left(M V \mathrm{O}_{2}\right)$, and myocardial lactate extraction at peak effect of captopril. Rate-pressure product, coronary sinus flow, and myocardial oxygen consumption decreased, while lactate extraction remained unchanged.

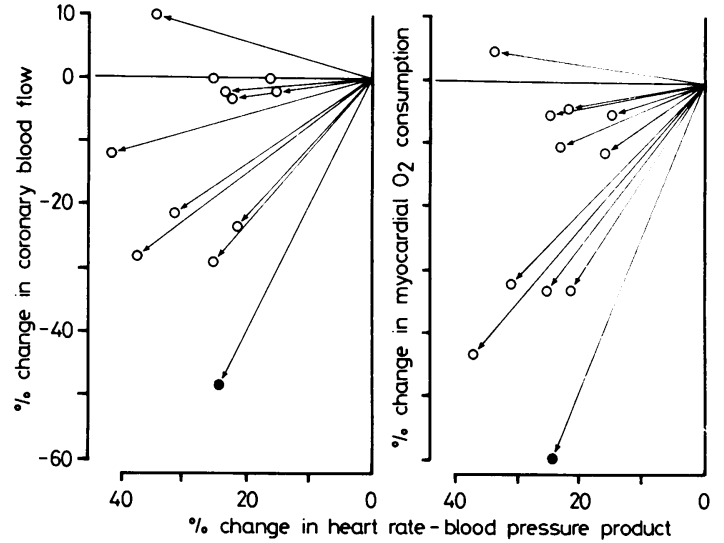

Fig. 2 Changes in stroke volume index (vertical axis) and pulmonary capillary wedge pressure (horizontal axis) during captopril treatment. Open circles $(O)$ indicate control values; solid circles are values obtained at time of peak effect of captopril; and arrows indicate changes after administration of captopril. In all but one patient $\left({ }^{\star}\right)$, stroke volume index increased, along with a decrease in pulmonary capillary wedge pressure, indicating improved left ventricular function.

response was obtained. In all patients, an increase in cardiac output and stroke volume, with a decrease in pulmonary capillary wedge pressure was observed, indicating enhanced left ventricular function. The mechanism of improvement in left ventricular function with captopril is likely to be related to the reduction of left ventricular outflow resistance, as systemic vascular resistance and arterial pressure fell in all patients. A pronounced reduction of right atrial and

Fig. 4 Relative changes in rate-pressure product (horizontal axis) and coronary blood flow and myocardial oxygen consumption (vertical axis) in individual patients at peak effect of captopril. The rate-pressure product decreased in all patients and coronary blood flow and myocardial oxygen consumption also decreased concurrently. The one patient who had myocardial lactate production is identified by the closed circle.

pulmonary capillary wedge pressures was also observed in many patients; such a decrease in systemic and pulmonary venous pressures may be partly the result of venodilatatory effects of captopril, which have been shown by plethysmographic studies. ${ }^{8}$ Angiotensin-II is a potent arteriolar constrictor, and the inhibition or attenuation of the effects of angiotensin-II by the converting enzyme inhibitors is likely to be associated with decreased arteriolar tone 
and systemic vascular resistance. Thus, with captopril, reduction of left ventricular ejection impedance and consequent increase in stroke volume and cardiac output is expected. Angiotensin-II, however, does not appear to cause any direct venoconstriction. ${ }^{13}$ Therefore, the venodilatation with captopril is likely to be the result of a mechanism other than the inhibition of the effects of angiotensin-II. Increased activity of the kinin peptides and decreased level of circulating norepinephrine have been observed after administration of converting enzyme inhibitors. Withdrawal of sympathetic venoconstrictor tone, therefore, is a possible mechanism of venodilatation with angiotensinconverting enzyme inhibitors. Whatever the mechanisms may be, reduction in pulmonary and systemic venous pressures with captopril are helpful for the relief of symptoms related to systemic and pulmonary venous hypertension. Pronounced hypotension occurring after the first dose of captopril has been observed in some patients in previous studies. In the present study, the initial dose of captopril was much smaller and the dose was gradually increased. With this dose titration, sudden pronounced hypotension could be avoided, though blood pressure fell in all patients. It appears, therefore, that during the initiation of captopril treatment in patients with normotensive heart failure, dose titration, starting with a smaller dose, is preferable to avoid sudden pronounced hypotension.

The present study also suggests that captopril consistently decreases myocardial oxygen demand and consumption. In all patients, the rate-pressure product, a commonly used index of myocardial oxygen demand, decreased. Changes in left ventricular diastolic volume were not directly determined in our patients. In all patients, however, there was a pronounced decrease in pulmonary capillary wedge pressure which should be associated with decreased left ventricular diastolic volume. As systolic arterial pressure decreased concomitantly, left ventricular wall stress, another major determinant of myocardial oxygen demand, must have declined during captopril treatment. As well as the decreased myocardial oxygen demand, there was also a decrease in myocardial oxygen consumption which was primarily caused by decreased coronary blood flow. In animal studies angiotensin-II has been shown to cause sustained vasoconstriction of the large conductance vessels, and a transient vasoconstriction of the smaller resistance vessels. ${ }^{14}$ Attenuation of the effect of angiotensin with captopril, and the possible decrease in angiotensininduced vasoconstriction, therefore, might be expected to preserve autoregulation. In such circumstances, coronary blood flow is largely influenced by the changes in myocardial oxygen demand. The present study suggests that with captopril, coronary blood flow and myocardial oxygen consumption are pre- dominantly governed by the changes in the haemodynamic determinants of myocardial oxygen demand.

In this study, in most patients there was no change in transmyocardial lactate extraction. In one patient, however, there was myocardial lactate production indicating myocardial ischaemia. In previous studies, lactate extraction of $5 \%$ or less has been regarded as evidence of myocardial ischaemia. ${ }^{15}$ Using this criterion, in one other patient, myocardial ischaemia might have been precipitated during captopril treatment. Recently, however, it has been shown that decreased lactate extraction to $5 \%$ or less can occur in normal subjects, and that evidence for lactate production is necessary for the definitive diagnosis of myocardial ischaemia. ${ }^{16}$ Whichever criteria are used for the diagnosis of myocardial ischaemia, it is clear that despite improved left ventricular function and decreased metabolic cost, myocardial ischaemia can be precipitated in some patients. In other clinical studies, recurrent episodes of angina during captopril treatment have been observed in occasional patients. ${ }^{17}$ The mechanism for lactate production in one patient in this study remains unclear. The ratepressure product decreased significantly and there was also a pronounced decrease in pulmonary capillary wedge pressure. Thus, lactate production occurred despite a significant reduction in myocardial oxygen demand, thus precipitating an imbalance between myocardial oxygen demand. In this patient, transmyocardial pressure gradient did not change significantly, suggesting that a decrease in subendocardial blood flow was unlikely. It is possible that coronary blood flow decreased in excess of that expected from the decrease in myocardial oxygen demand, thus precipitating an imbalance between myocardial oxygen sumply and demand.

The present study suggests that captopril is a potent vasodilator and has the potential to improve left ventricular function in patients with chronic heart failure. Improved left ventricular function with captopril is usually associated with decreased metabolic cost, and myocardial ischaemia occurs infrequently.

\section{References}

1 Heel RC, Brogden RN, Speight TM, Avery GS. Captopril: a preliminary review of its pharmacological properties and therapeutic efficacy. Drugs 1980; 20: 409-52.

2 Gavras H, Brunner HR, Turini GA, et al. Antihypertensive effect of the oral angiotensin converting-enzyme inhibitor, SQ 14,225 in man. $N$ Engl f Med 1978; 298: 991-5.

3 Davis R, Ribner HS, Keung E, Sonnenblick EH, Lejmetel TH. Treatment of chronic congestive heart failure with captopril, an oral inhibitor of 
angiotensin-converting enzyme. $N$ Engl f Med 1979; 301: 117-21.

4 Turini GA, Brunner HR, Gribic M, Waeber B, Gavras $\mathrm{H}$. Improvement of chronic congestive heart failure by oral captopril. Lancet 1979; i: 1213-5.

5 Ader R, Chatterjee K, Ports T, Brundage B, Hiramatsu $\mathrm{B}$, Parmley $\mathrm{W}$. Immediate and sustained haemodynamic and clinical improvement in chronic heart failure by an oral angiotensin-converting enzyme inhibitor. Circulation 1980; 61: 931-7.

6 Dzau VJ, Colucci WS, Williams GH, Curfman G, Meggs L, Hollenberg NK. Sustained effectiveness of converting-enzyme inhibition in patients with severe congestive heart failure. $N$ Engl f Med 1980; 302: 1373-9.

7 Levine TB, Franciosa JA, Cohn JN. Acute and long-term response to an oral converting enzyme inhibitor, captopril, in congestive heart failure. Circulation 1980; 62: 35-41.

8 Awan NA, Evenson MK, Needham KE, Win A, Mason DT. Efficacy of oral angiotensin-converting enzyme inhibition with captopril therapy in severe chronic normotensive congestive heart failure. Am Heart $\mathcal{F}$ 1981; 101: 22-31.

9 Forrester JS, Ganz W, Diamond G, McHugh T, Chonette SW, Swan HJC. Thermodilution cardiac output determination with a single flow-directed catheter. Am Heart $\mathcal{f}$ 1972; 83: 306-11.

10 Mathey DG, Chatterjee K, Tyberg JV, Lekven J, Brundage B, Parmley WW. Coronary sinus reflux: a source of error in the measurement of thermodilution coronary sinus flow. Circulation 1978; 57: 778-96.
11 Ganz W, Tamura K, Marcus HS, Donoso R, Yoshida S, Swan HJC. Measurement of coronary sinus blood flow by continuous thermodilution in man. Circulation 1971; 44: 181-95.

12 Loomis ME. An enzymatic fluorometric method for the determination of lactic acid in serum. $f$ Lab Clin Med 1961; 57: 966-9.

13 Cohn JN. Relationship plasma volume changes to resistance and capacitance vessel effects of sympathomimetic amines and angiotensin in man. Clin Sci 1966; 30: 267-78.

14 Cohen MV, Kirk ES. Differential response of large and small coronary arteries to nitroglycerin and angiotensin. Autoregulation and tachyphylaxis. Circ Res 1973; 33: 445-53.

15 Neill WA. Myocardial hypoxia and anaerobic metabolism in coronary heart disease. Am $\mathcal{f}$ Cardiol 1968; 22: 507-15.

16 Gertz EW, Wisneski JA, Neese R, Houser A, Korte R, Bristow JD. Myocardial lactate extraction: multi-determined metabolic function. Circulation 1980; 61: 256-61.

17 Baker KM, Johns DW, Ayers CR, Carey RM. Ischemic cardiovascular complications concurrent with administration of captopril. A clinical note. Hypertension 1980; 2: $73-4$.

Requests for reprints to Professor Kanu Chatterjee, Room 1186 Moffitt, University of California, San Francisco, California 94143, USA. 